\title{
Cyprus and the Near East
}

\author{
Paul Åström
}

\begin{abstract}
Cypriote archaeology has flourished during the period, particularly at the Göteborg University and the Museum of Mediterranean Antiquities in Stockholm, and monographs and articles on Cypriote sites, pottery, chronology, religion, iron artefacts etc. have appeared.

Paul Åström, Department of Ancient Culture and Society, Göteborg University, Västra Hamngatan 3, S-411 17 Göteborg, Sweden.
\end{abstract}

The grand old man of Cypriote archaeology, Einar Gjerstad, passed away in 1988. Three of his students have summarized his achievements: Åström (1988c, 1988i, 19881, 1989c), Gierow (1988a-b) and Styrenius (1988).

The first volume of the late professor J. R. Stewart's magnum opus, his corpus on Early Cypriote artefacts, edited by Eve Stewart and Paul Åström, has appeared posthumously with commemorative words by the latter (Åström 1989j). Monographs on Cypriote excavated sites have appeared on Ayia Paraskevi and Vasilia (Hennessy, Eriksson \& Kehrberg 1988) and on Katydhata (Åström 1989h). Pottery from earlier excavated, Cypriote sites has been re-examined: Nitovikla by Hult 1989 and Kalopsidha by Sjödin 1988. A great number of prehistoric Cypriote skulls have been examined in a monograph from a medico-anthropological, archaeological and micro-chemical point of view by Peter M. Fischer (1986).

General studies have appeared on prehistoric Cyprus (Åström 1987c, 1990b) and its foreign relations and trade (Åström 1986c, Åström 1989i), especially with Anatolia (Åström 1989b), the Dodecanese ( ström 1988k), Greece (Åström 1987i) and Egypt (Jacobsson 1987).

The results of the Swedish excavations at the Late Cypriote Bronze Age site at Hala Sultan Tekke have been published in a monograph (Åström, Eriksson et alii 1989) and in a number of articles. General syntheses on the results (Åström 1986b, 1986f, $1989 \mathrm{~g}, 1990 \mathrm{c}$ ) and annual reports have appeared (Åström 1986a, 1987a, 1988a, 1988d, $1988 \mathrm{e}, 1988 \mathrm{f}, 1988 \mathrm{~g}, 1989 \mathrm{a}, 1989 \mathrm{~d}, 1989 \mathrm{e}$, 1989f, 1990a; cf. Erikson 1987).

The chronology of the Middle Cypriote Bronze Age has been treated by Åström (1986e, 1987b). The discovery of a Cypriote White Painted Pendent Line Style jug in Kuiltepe IB is particularly important for synchronisms with other areas where this pottery style has been found.

In a study of the Late Cypriote shaft graves Karin Niklasson-Sönnerby (1987) has discussed the burial customs in the last phase of the Bronze Age.

A number of articles on Cypriote religion have been published by Paul Åström in the Journal of Prehistoric Religion and elsewhere. He has treated the universal phenomenon of inverted vases $(1987 \mathrm{~g})$, intentional destruction of grave-goods (1987f), votive deposits in the Late Bronze Age (1987l) and triton shells in East Mediterranean cults (Åström \& Reese 1990). He has also discussed the interpretation of a cult scene on a Red Polished terracotta model (Åström 1987h, 1988b). Jan Bergman (1987) has written a review of Sophocleous' Atlas de représentation chypro-archaïques des 
divinités. Cecilia Beer discusses the religious significance of the so-called temple-boys (1987).

In a series of studies Eva Rystedt (1986, 1987a, 1988a-c, 1990) has interpreted the scenes and motifs on Mycenaean pictorial vases and identified their painters; many of their products have been found by the Swedish Cyprus Expedition in Cyprus and are now in the Museum of Mediterranean Antiquities in Stockholm. Taking a vase in the shape of a hedgehog in the same museum as a starting point, she has also listed a number of similar, Mycenaean and later vases, two of which come from Cyprus (1987b). An unusual pictorial vase from Hala Sultan Tekke of Late Cypriote III "the Hippocampus krater" - was published by Paul Åström (1988h). A bibliography on Mycenaean pottery in Italy, Asia Minor, Cyprus and the Near East was compiled by Åström (1986d).

Enamel defects in teeth from a prehistoric Cypriote population have been studied by Fischer and Norén (1986). Fischer (1989) and Fischer and Lodding (1987) have shown the use of secondary ion mass spectrometry (SIMS) in archaeometry and proposed a new dating method based on the penetration of fluorine in teeth. Aström and Fischer (1987) demonstrate the use of metal-detector in scientific excavations in Cyprus and Greece. Kleiner and Åström (1989) have shown that it is possible to register sounds in clay and to play up the sounds after firing; they illustrate their article with the wheel-marks of a Cypriote amphora.

Analyses of Red Polished black-topped knob lug bowls suggest that the vases were placed upright in sand on a kiln floor and fired reducingly (Waern-Sperber 1988 and Makundi, Waern-Sperber \& Ericsson 1989). Kathryn Eriksson demonstrates how Red Lustrous Wheel-made pilgrim flasks were manufactured (1988).

Claude Björk (1990) proposes to attribute to the same painter a number of $\mathrm{Bi}$ chrome vases dating from Cypro-Geometric II to Cypro-Archaic I and decorated with birds.

An analytical study by Åström, Maddin, Muhly and Stech (1986) showed that the 11 th century B.C. artefacts from Idalion were thoroughly carburized, quenched and sometimes tempered. A study of the funerary contexts of iron by the same team shows that iron usually occurs in rich tombs and is fairly frequently associated with gold in the Cypriote Iron Age.

Örjan Wikander (1986) has commented on two Corinthian pan-tiles dating from the Classical period, found by the Swedish Cyprus Expedition at Marion.

A major new archaeological expedition at Tell Abu-Kharaz in Jordan has been initiated by Peter M. Fischer. In the first campaign in 1989 a sanctuary and town walls from the Early and Late Bronze Ages and from the Iron Age were discovered ( $₫$ ström 1990a: 3-4).

English revised by Laura Wrang.

\section{REFERENCES}

Åström, P. 1986a. Antikens kultur och samhällsliv. Forskning vid Humanistiska fakulteten 1985/86, Göteborgs universitet. 1-5.

- 1986b. Hala Sultan Tekke - an international harbour town of the Late Cypriote Bronze Age. Opuscula Atheniensia 16. 7-17.
- 1986c. Hala Sultan Tekke and its foreign relations. Acts of the international archaeological symposium "Cyprus between the Orient and the Occident", 8-14 September 1985. Nicosia. 63-68, pls. 4-5.

- 1986d. Italy, Asia Minor, Cyprus and the Near 
East. In: Mountjoy, P. A. Mycenaean decorated pottery. Studies in Mediterranean archaeology 73. Göteborg. 226-228.

1986e. The Middle Minoan chronology again. Pepragména tồ $E^{\prime}$ diethnoûs kretologikoû synedriou 1. Heraklion. 36-44.

- 1986f. Midea och Hala Sultan Tekke - kring katastrofer vid slutet av bronsåldern. Medusa 7:2. 30-37.

- 1987a. Antikens kultur och samhällsliv. Forskning vid Humanistiska fakulteten 1986/87, Göteborgs universitet. 1-8.

- 1987b. The Chronology of the Middle Cypriote Bronze Age. In: Åström 1987d. 57-66.

- 1987c. Cyprus and the Near East. Swedish Archaeology 1981-1985. Stockholm. 201-203.

- 1987d-e. (Ed) High, Middle or Low? Acts of an international colloquium on absolute chronology held at the University of Gothenburg 20th - 22nd August 1987. 1 and 2. Studies in Mediterranean archaeology. Pocket-books 56 and 57. 1987.

- 1987f. Intentional destruction of grave goods. Aegaeum 1. 213-217.

- 1987g. Inverted vases in old world religion. Journal of Prehistoric Religion 1. 7-16.

1987h. Min bild. Offerscen. Synpunkt. 12-13.

- 1987i. Relations between Greece and Cyprus in the Late Bronze Age. 6th international colloquium on Aegean prehistory, The Prehistoric Aegean and its relations to adjacent areas, Greece, 30 Aug. 5 Sept. 1987. Summaries. Athens. 17.

- 1987j. [Review of] Bernhard-Walcher, A. Bronzezeitliche Keramik aus Zypern. Wien 1984. Bonner Jahrbücher 187. 682f.

- 1987k. [Review of] Matthäus, H., Metallgefässe und Gefässuntersätze der Bronzezeit, der geometrischen und archaischen Periode auf $C y$ pern mit einem Anhang der bronzezeitlichen Schwertfunde auf Cypern. Munich 1985. Germania 65. 473-475.

- 19871. Votive deposits in the Late Cypriote Bronze Age. Boreas 15. Uppsala. 177-179. - 1988a. Antikens kultur och samhällsliv. Forskning vid Humanistiska fakulteten 1987/88. Göteborg. 1-11.

- 1988b. A Cypriote cult scene. Journal of Prehistoric Religion 2. 5-11.

- 1988c. Einar Gjerstad - Den cypriska arkeologins fader. Dagens Nyheter 21.1.1988.

- 1988d. Excavations near the Hala Sultan Tekké mosque. Annual Report of the Director of Antiquities Cyprus 1987 [pr.1988]. 47-48.

- 1988e. Fouilles de Hala Sultan Tekké (Mission suédoise). Bulletin de Correspondance Hellénique 112. 824-826.

- 1988f. Hala Sultan Tekke. Bead Study Trust Newsletter 11, April 1988. 2.

- 1988g. [Hala Sultan Tekke]. Antik-bulletinen. 1988:2. Lund 1, 4.

- 1988h. The Hippocampus krater. Report of the Department of Antiquities, Cyprus. 173-176.

- 1988i. Professor Einar Gjerstad in memoriam. Hellenika 44. 2.

- 1988j. 'Publisher's preface'. In: Stewart, E. \& Åström, P. (Eds.), J.R. Stewart. Corpus of Cypriot artefacts of the Early Bronze Age. Studies in Mediterranean archaeology 3:1. Göteborg. 4.

- 1988k. Relations between Cyprus and the Dodecanese in the Bronze Age. In: Dietz, S. and Papachristodoulou, I. (Eds.). Archaeology in the Dodecanese. Copenhagen. 76-79.

- 19881. Rättelse. Hellenika 45. 2.

- 1989a. Antikens kultur och samhällsliv. Forskning vid Humanistiska fakulteten 1988/89. Göteborgs universitet. 1-9.

- 1989b. Early connections between Anatolia and Cyprus. In: Emre, K., et alii (Eds.). Anatolia and the Ancient Near East, Studies in Honor of Tahsin Özgüc. Ankara. 15-17.

- 1989c. Einar Gjerstad 30/10 1897 - 8/1 1988. Minnesord. Ärsberättelse. Kungl. Humanistiska Vetenskapssamfundet i Lund 1988-1989. Lund. 19-27.

- 1989d. Excavations near the Hala Sultan Tekké mosque. Annual Report of the Director of Antiquities Cyprus 1988 [pr.1989]. 44.

- 1989e. Fouilles de Hala Sultan Tekké (Mission suédoise). Bulletin de Correspondance Hellénique 113.824.

- 1989f. Hala Sultan Tekke. Antik-Bulletinen 1989:2.

- 1989g. Hala Sultan Tekke väcks ur sömnen. Populär arkeologi 7:3. 4-7.

- 1989h. Katydhata, A Bronze Age site in Cyprus. With a chapter by P. Flourentzos. Studies in Mediterranean archaeology 86. Partille.

- 1989i. Trade in the Late Cypriote Bronze Age. In: Peltenburg, E. (Ed.). Early society in Cyprus. Edinburgh. 202-208.

- 1990a. Antikens kultur och samhällsliv. Forskning vid Humanistiska fakulteten 1989/90. Göteborg. 1-10. 
- 1990b. Cypern: Förhistoria. Nationalencyklopedin 4.

- 1990c. Hala Sultan Tekke. Medusa 11:2. 37-38.

Åström, P., Eriksson, K. et alii 1989 Hala Sultan Tekke 9. Trenches 1972-1987. With an index for volumes 1-9. Studies in Mediterranean archaeology 45:9. Göteborg 1989.

Åström, P. \& Fischer, P. M., 1987. Metal-detecting in Cyprus and Greece'. Antiquity 61: 232. 266f.

Åström, P., Maddin, R., Muhly, J. D. \& Stech, T. 1986. Iron artifacts from Swedish excavations in Cyprus. Opuscula Atheniensia 16. 27-41.

Åström, P. \& Reese, D. 1990. Triton shells in East Mediterranean cults. Journal of Prehistoric Religion 3-4. 5-14.

Beer, C. 1987. Comparative votive religion: the evidence of children in Cyprus, Greece and Etruria. In: Linders, T. \& Nordquist, G. Gifts to the gods. Boreas 15. Uppsala. 21-29.

Bergman, J. 1987. [Review of] Sophocleous, S. Atlas des représentations chypro-archaïques des divinités. Journal of prehistoric religion 1. 55-57.

Björk, C. Another Bichrome Ware painter from Cyprus? Medelhavsmuseeet. Bulletin 25. 1118.

Erikson, F. 1987. Utgrävning på Cypern. Bronsåldersstaden berättar. Göteborgs-Posten 8.7. 1987.

Eriksson, K. 1988. Pilgrim flask: How were they made? Report of the Department of Antiquities, Cyprus. 177-180.

Fischer, P. M. 1986. Prehistoric skulls. A medicoanthropological, archaeological and microchemical investigation. Studies in Mediterranean archaeology. 75. Göteborg.

- 1989. Arkeometri. Mycket mänskligt. Humanistisk forskning vid Göteborgs universitet 2. Göteborg. 23-27.

Fischer, P. M. \& Norén, G. 1988. Enamel defects in teeth from a prehistoric Cypriot population. Ossa 13, 1986-1987. 87-96.

Fischer, P. M. \& Lodding, A. 1987. High, Middle or Low? Acts of an international colloquium on absolute chronology held at the University of Gothenburg 20th - 22nd August 1987. 3. Studies in Mediterranean archaeology. Pocketbook 80. 142-149.

Gierow, P. G. 1988a. Einar Gjerstad. Kungl. Vitterhets Historie och Antikvitets Akademiens Årsbok. 38-40. 1988b. Einar Gjerstad. Vetenskapssocieteten $i$ Lund. Årsbok. 171-176.

Hennessy, J. B., Eriksson, K. O. \& Kehrberg, I. C. 1988. Ayia Paraskevi and Vasilia. Studies in Mediterranean archaeology 82. Göteborg.

Hult, G. 1989. En utgrävning av en utgrävning. Mycket mänskligt. Humanistisk forskning vid Göteborgs universitet 2. Göteborg. 18-22.

Jacobsson, I. 1987. Early relations between Cyprus and Egypt. Referate vom Kolloquium zur Ägäischen Vorgeschichte, Mannheim 20 22-2. 1986. Schriften des Deutschen ArchäologenVerbandes. 9. Mannheim. 177-184.

Kleiner, M. \& Åström, P. 1989 Kan krukor tala? Mycket mänskligt. Humanistisk forskning vid Göteborgs universitet 2. Göteborg. 28-31.

Makundi, I. N., Waern-Sperber, A. \& Ericsson, T. 1989. A Mössbauer study of the black colour in Early Cypriote and Nubian C-group blacktopped pottery. Archaeometry 31. 54-65.

Niklasson-Sönnerby, K. 1987. Late Cypriote shaft graves: burial customs of the last phase of the Bronze Age. Aegaeum 1. 219-225.

Rystedt, E. 1986. The foot-race and other athletic contests in the Mycenaean world. The evidence of the Mycenaean vases. Opuscula Atheniensia. 16. 103-116.

- 1987a. Oxhide ingots or camp stools? Notes on a motif in Mycaenean pictorial vase-painting. Report of the Department of Antiquities, $C y$ prus. 49-55.

- 1987b. Vases in the shape of hedgehogs - Mycenaean and later. Medelhavsmuseet. Bulletin 22. 28-39.

- 1988a. Bastard animals on a Mycenaean krater in London. Report of the Department of Antiquities, Cyprus. 267-270.

- 1988b. Mycenaean runners - including apobatai. In: French, E. B. \& Wardle, K. A. (eds.). Problems in Greek prehistory. Papers presented at the Centenary conference of the British School of Archaeology at Athens. Manchester, April 1986. Bristol. 437-442.

- 1988c. New light on a Mycenaean pictorial vase painter. Medelhavsmuseet. Bulletin 23. 21-32.

- 1990a. On distinguishing hands in Mycenaean pictorial vase-painting. Opuscula Atheniensia 18. 167-176.

Sjödin, S. 1988. Bronze Age pottery sherds from Cyprus. Further supplementary material from Kalopsidha Trench 9. Opuscula Atheniensia 17. 143-165. 
Styrenius, C.-G. 1988. Einar Gjerstad 30/10 1897 8/1 1988. Medelhavsmuseet. Bulletin 23. 3-8.

Waern-Sperber, A. 1988. Mössbauer spectroscopy and quantative chemical analyses of Early Cypriote black topped pottery. Opuscula
Atheniensia 17. 191-197.

Wikander, Ö. 1986. Two Cypriote pan-tiles in Stockholm. Medelhavsmuseet. Bulletin 21. 44-48. 
